\title{
Schema for Investigating Coasts and Beaches
}

\author{
Poh Poh Wong
}

\section{ABSTRACT}

Based on accumulated field experience, the author proposed a schema for the study of coasts and beaches. Six sequential steps are recommended in knowing: (1) the tidal range, (2) waves and coastal processes, (3) coastal habitats, (4) extreme changes, (5) spatial variation, and (6) human actions. This provides a helpful start for beginners and a basis for further details and elaboration for the more knowledgeable.

Keywords: coasts, beaches, investigation, schema.
Published Online: November 30, 2020

ISSN: $2684-446 \mathrm{X}$

DOI :10.24018/ejgeo.2020.1.6.87

\section{Poh Poh Wong*}

School of Social Sciences, University of Adelaide, Australia.

(e-mail: wong3921@gmail.com)

*Corresponding Author

\section{INTRODUCTION}

About $70 \%$ of Earth's surface is covered by water and results in about $620,000 \mathrm{~km}$ of coastline. Over one-third of total human population lives within $100 \mathrm{~km}$ of an oceanic coast [1]. Basically, the coast is a highly dynamic zone at the interface between land, sea, and air. For the people living near the sea, especially those in tropical regions and love their beaches, they do recognize the general character and behaviour of beaches more easily than others.

My formal experience with coasts started with the completion of an undergraduate study on Singapore's coasts [2]. In 1971 I completed my Ph.D. dissertation on beach changes and sediment movement in a low energy environment in Barbados [3]. I was fortunate to benefit from a short attachment with Louisiana State University Coastal Studies Unit for fieldwork on Santa Rosa Island in August 1969 when Hurricane Camille struck. I gained a good idea of before and after effects of hurricane impact on Santa Rosa beaches.

To date, I have been to more than 30 countries to study or observe various types of coasts, including both physical and human aspects. During my career of more than 40 years at the University of Singapore (renamed National University of Singapore in 1980) my research has expanded from coastal geomorphology to coastal tourism, coastal zone management, small islands, climate change, sea-level rise, tsunami impacts, and mangroves. The studies were conducted mainly in countries of Southeast Asia and East Asia. Although retired from university service in 2010, I still make investigative visits to coasts and beaches during conferences or on holidays.

From 1960s to 2010s, I acquired major texts on coasts and beaches [4]-[24]. Additional useful information came from the series of manuals by U.S. Army Corps of Engineers (USACE) from the shore protection manual to the coastal geology and engineering manuals [25]-[27]. In recent years and more seriously, beaches are fast disappearing [28], [29]. Over time as usual, information is updated, re-interpreted or examined from a different or new perspective as new texts are published.

I reach an early realization that while knowledge on coasts and beaches keep on changing, the features must have behaved the same over millions, thousands, and hundreds of years ago and are still the same today. However, our efforts to understand them is incomplete and not fully. In the light of this, I would like to contribute some basic principles in understanding beaches and coasts. In a way, this links up my work of more than 40 years on coasts and beaches into a simple schema for observing and studying these features.

The beginning of this schema was the fieldwork on the west coast in Barbados for my Ph.D. [3]. While in the field, I realized a few significant relationships of the crescentic sandy beaches at an early stage. First, the significant differences in the height of beach (measured at the berm crest) in a bay are related to wave energy or wave height. Second, the profile changes are related to planform changes, e.g. beach erosion means the planform is pushed landward while beach deposition means the planform is pushed seaward. Third, and more importantly, what is eroded at one part of the bay is related to deposition at another part of the bay, i.e. profile and planform changes are related spatially. From this first study, I expanded such observations to other beaches and coastal types, e.g. beaches with rhythmic topography, J-shaped bays, and other coastal ecosystems.

This simple schema developed here for investigating the coast and its features represents a kind of capsule or helicopter view for a better and quick understanding of the coast. As nature or the physical environment cannot talk to us, the next best thing is to observe or monitor it carefully. Through both repetitive and comparative work, simple and basic principles can be formed to understand coasts and beaches. 
This short paper outlines certain key steps or procedures to have a quick understanding of any coast based on my accumulated education gained through field work and experience and not from books alone. Hopefully, this can be helpful to others who are starting on their coastal studies, especially those without coastal background. This does not replace such similar or more advanced information in texts or others with their advice. The schema can also be a rapid check-off tool for the assessment of coasts in climate change and sea-level rise impacts on coasts. The schema could be further revised, developed, and enlarged into a basic text in the study of coasts.

This schema is meant to apply to any coast in the world, except for the polar regions where coasts are frozen by ice. In any coastal country, there would be various types of hard rock coasts to sandy coasts. In the tropics, one would expect also corals and mangroves where conditions are suitable. And all coasts are subject to several basic processes - tides, waves, currents, and human impact.

\section{SCHEMA EXPLAINED}

In general, a schema describes a pattern of thought that organizes categories of information and the relationships among them. For the coasts and beaches, the sequence of thought and information is crucial as coasts and, in particular, beaches vary across widely over a narrow band of space. Correct cognizance or understanding is important for more detailed studies to be carried through measurements and sample studies to be conducted.

Coastal geomorphological texts typically go into the various types of coasts, coastal processes, and study methodologies; some would include coastal management and more recent issues dealing with climate change and sustainable or resilient coasts. The equipment used in beach and coastal study has improved rapidly over time from basic survey instruments in the field and aerial photographic interpretation to satellite imagery and other remote sensors. But to my knowledge there is no schematic approach similar to the one outlined in this paper.

The schema involves consideration of several major key steps in sequence or be knowledgeable of them in the study of any coastal stretch or beach, except for the polar regions. Sequentially, six broad items need to be considered; the first three items can be considered broadly as initial and mandatory and next three can be considered broadly as adding details over time and space to gain a better or more complete picture.

\section{A. Tidal Range}

The first key step is to know the tidal range of the coasts and the beaches. Prior information can be obtained from published sources or from recognition of field features that indicate the tidal zone of the coast or beach. Note that as tidal range can range from low at neap tide to high at spring tide, one has to deal with the average tidal range.

The tidal range has implications on the features and processes on the coast. The intertidal zone (foreshore zone for beach) is impacted by the tides and runup from waves. The area seaward of the intertidal area (nearshore zone for beach) remains in the water all the time and is affected mainly by waves and currents. The area above the tidal range (backshore zone for beach) is influenced by wind, producing sand dunes, or by extreme events, e.g. storms. The basic terminology on beaches and coasts has been dominated by American works, particularly the USACE manuals on coasts.

It is necessary to understand more about tidal range if you are comparing coasts and beaches under different tidal ranges. The tidal range can be classified into micro $(<2 \mathrm{~m})$, meso ( 2 to $4 \mathrm{~m}$ ) or macro (>4 m) [30].

Within a 24-hr period, tides themselves are classified into diurnal (one high and one low per day), semi-diurnal (two highs and two lows per day), and mixed (two unequal highs and two unequal lows per day). The tidal range and the type of tide have implications on the "frequency" and "magnitude" of coastal processes acting on the coast or beach [31]. Tidal range is absent along the shores of lakes.

\section{B. Waves and Coastal Processes}

The second key step is to be fully cognizant of the waves and other coastal processes, especially currents, affecting the coast. For these normal processes, take note of their extent of influence or action within the tidal range and include those in the nearshore zone and any above the high tide mark. Also, include the alongshore processes and the extent of topographic changes alongshore, especially with the presence of other features, e.g. headlands, lagoons, dunes, estuaries, spits, etc.

Taking the example of a sandy coast, the basic aspect of waves and processes is to note the difference where a surf zone is present or absent. A surf zone is where waves break initially and reform to move across a zone of breakers before reaching the shore. Where there is no surf zone, waves break near the shore and normally at a step of coarser material.

More important is the consideration of the seasonal cycle of processes as seasonal changes can be very contrasting. Therefore, take note and recognize their extent of seasonal impact. Check basic climatic data for the contrasting seasons, for example, monsoons with winds from different directions in tropical regions. After working on many beaches, one should be able to distinguish the features for the season and also have some idea of the features of the previous season, e.g. "summer" and "winter" berms on beaches, erosional scarps on the foreshore, swash marks on berms, types and extent of nearshore topography.

An important point is to note where deep-water waves undergone changes to have an impact on the coast. A simple rule is that deep-water waves start to shoal at about the depth of half their wave length. Admiralty or bathymetric charts provide an initial picture of the depths and some idea of the wave energy arriving at the coast.

\section{Coastal Habitats}

Third, one can then consider one or more of the basic coastal habitats or coastal environments based on geological and/or biological criteria. Coastal geomorphological texts have different emphasis by excluding some, combining some or including other environments in the following general list: 
(a) ice/polar coast (in polar region),

(b) hard coast/cliff,

(c) gravel beach/coast,

(d) sandy beach/coast (include dunes, barriers and lagoons

which are subdivisions within this broad category),

(e) estuary,

(f) mangrove coast (mainly in tropics),

(g) coral coast (mainly in tropics),

(h) salt marsh coast (temperate region), and

(i) seagrass coast (both temperate and tropical regions). For shores bordering lakes and have no tidal range, consider which of the above habitats or coastal environments is applicable.

Within the tropical zone, there are two distinct tropical coastal environments - corals and mangroves as discussed by Zenkovich [5]. Southeast Asia has more than one third of global mangroves and corals.

For each coastal habitat or environment, try to obtain a complete picture, including the main features and peculiar characteristics, and the importance and role of the biodiversity. For example, examine the type of coastal forests and backshore/berm vegetation and their role on sandy beaches. Although mangroves are found in mainly in muddy environments, they can establish in non-muddy environments, e.g. on coral reefs, sandy beaches, and gravels.

\section{Extreme Events}

Four, once the major coastal habitats are understood, together with seasonal influences, then it is easier to understand their impact by storms or under the influence of a dominant trend - erosion or deposition.

Extreme changes are low frequency but high magnitude events and include changes from storms, tsunamis, and other natural disasters. The changes are dramatic but less easy to observe. One needs to take advantage of the opportunity to observe immediately after such events.

I give two examples of opportunities to investigate extreme changes on the coast.

Extreme high tides occur a few times during a year. A weekly magazine reported that extreme high tides would occur globally from 7-12 February 1974 due to the alignment of the moon, sun, and earth. I took note of the information and made observations over two days in Singapore; this was the highest tide recorded to date and the results were published as short-term impacts to beaches [32] and as an indicator of a future 1-m sea-level rise [33].

In the aftermath of the Indian Ocean tsunami in December 2004, I took the opportunity to examine its impacts on tourism on Phuket Island, Thailand, initially and subsequently expanded fieldwork to Aceh in Indonesia, Sri Lanka, and Tamil Nadu in India. I went back to Aceh and Thailand several times and the impacts and recovery of Aceh's coast and the Thai tourist coasts from the tsunami were published subsequently [34], [35].

One significant impact of climate change on the coast is sea-level rise which has implications for erosion. It should be noted that sea-level rise is a slow-onset event and coastal erosion cannot be easily attributed to sea-level rise. The relationship between sea-level rise and coastal erosion can be established by statistical analysis over a long period. The impact of increasing temperature and acidification on corals and biological environments are more easily observed and can be attributed to climate change.

\section{E. Spatial Variation}

Fifth, where possible try to obtain two perspectives of each of the above habitats or coastal environment over time, one from land to sea and another alongshore. Instrumental profiles, aerial or satellite photographs, including UAVs (unmanned aerial vehicles) can be used.

Based on the sandy coast, the cross-beach or profile from land to sea is to provide a clear idea of the normal or average profile and distinct changes due to tidal cycle, seasons, storm impact and recovery, or long-term trend. While the majority of coastal habitats or coastal environments do not vary much from the mean, it is the sandy coast that has more diversity and much has been written on these coasts. Much emphasis has been placed on the presence of the surf zone on American and Australian coasts. But it was the Australian coastal environment that provides enough diversity for a study leading to the morphodynamic model of sequential beach changes by Short who was already familiar with such beaches in U.S.A. [36]. The surf zone is not present on many other beaches; instead a gravel step is present [5], [7].

The alongshore beach profile changes focus basically on changes arising from processes that are dominantly unidirectional or reversal due to seasonal changes. Alongshore "interruptions" can be caused by: (a) immobile features such as projecting headlands, whether natural or artificial, resulting in the formation of distinct bays on the downdrift side [37] and (b) mobile features such as extending spits from river mouths which lead to the migrating erosion of a sandy coast in the same direction as seen on the east coast of Peninsular Malaysia.

A distinct zonation based strongly on morpho-biological factors is present on both mangrove and coral coasts from land to sea. Mangroves have distinct zonation with dominant species based on the duration of the tidal inundation (number of days per annum). Coral coasts, irrespective of whether they are fringing reefs, patch reefs, barrier reefs or atolls also have distinct zones (back-reef, reef flat, reef crest, reef slope, forereef slope) depending on depth, wave exposure, and distance from shore [38].

Hard coasts or cliffs have distinct profiles - with shore platforms (horizontal or gentle seaward sloping) or plunging. As cliffs recede under erosion, sea caves, arches, and stacks form in weaker rocks with the erosion often controlled by bedding planes and fractures [39].

\section{F. Human Actions}

Consider human actions or coastal constructions only after understanding the above natural coasts and their processes. Coastal processes and landforms are often made more complicated by human actions to stop erosion or measures taken to create harbours and other facilities.

Historically, human modification of the coasts has evolved in relation to the deployment of various types of structures. The full range is best exemplified in the works of the U.S. Army Corps of Engineers [40], [41]; the trends in coastal protection increasingly incorporate nature and shift towards 
soft but novel, eco-friendly methods.

In general, coastal protection measures could be categorized as follows: (a) hard structures, (b) soft structures, (c) mixed/hybrid structures, (d) ecological structures (EBA or ecosystem-based adaptation) with mangroves dominating corals and seagrasses and a wider term "nature-based solutions" (NbS) in use for natural and hybrid measures [42], and (e) new approaches including "Building with water" [43], "Living with water" [44], "Give back land to the sea," and "Floating or sea-encircled artificial dwelling mounds" [45]. The new approaches are more applicable to urban planning in cities liable to coastal flooding with U.S.A. having a handbook for climate change adaptation in the coastal areas of the country [46].

A recent review of present and future measures addressing sea-level rise in the Small Island Developing States (SIDS) [47] found the following results: EBA was most cited by the SIDS for future use; significant topographic features have not been given sufficient attention to address sea-level rise; floatation, although used on few SIDS (e.g. stilt houses, overwater tourist bungalows) should be considered seriously given new materials and technologies for floating and amphibious structures; and some new measures can be designed to imitate nature or natural processes.

\section{CONCLUSION}

The above simple schema provides one to recognize and understand in a faster way the various types of coasts and beaches and their behaviour over time and space. Further details and elaboration can be worked appropriately, depending on the type and level of research to be carried out for a particular stretch of coast, the type of habitat, the impacts of natural processes occurring normally or at extreme levels, and the types and extent of human activities. The schema could also be useful for a text to be developed or expanded along similar lines.

\section{REFERENCES}

[1] "Living ocean," NASA Science. Available: https://science.nasa.gov/earth-science/oceanography/living-ocean.

[2] P.P. Wong, "The coastal types of Singapore," Honours Year Academic Exercise, Department of Geography, University of Singapore, Singapore, 1965/66.

[3] P. P. Wong, "Beach changes and sand movement in low energy environments, west coast, Barbados," Ph.D. dissertation, Department of Geography, McGill University, Montreal, Canada, 1971.

[4] F.P. Shepard, Submarine Geology, $2^{\text {nd }}$ ed. New York: Harper \& Row, 1963.

[5] V.P. Zenkovich, Processes of Coastal Development, Edinburgh: Oliver and Boyd, 1967.

[6] F.P. Shepard and H.R. Wanless, Our Changing Coastlines, New York: McGraw Hill, 1971.

[7] C.A.M. King, Beaches and Coasts, $2^{\text {nd }}$ ed. London: Edward Arnold, 1972.

[8] D.L. Davies, Geographical Variation in Coastal Development, New York: Hafner, 1973.

[9] W. Bascom, Waves and Beaches, New York: Anchor Press, 1980.

[10] E.C.F. Bird, Coasts: An Introduction to Coastal Geomorphology, $3^{\text {rd }}$ ed. Oxford: Blackwell, 1984.

[11] J. Pethick, An Introduction to Coastal Geomorphology, London: Routledge, 1984

[12] E.C. Bird and M.L. Schwartz, eds., The World's Coastline, New York: Van Nostrand Reinhold, 1985.
[13] R.A. Davies, Jr., ed., Coastal Sedimentary Environments, New York Springer-Verlag, 1985

[14] P.D. Komar, Beach Processes and Sedimentation, $2^{\text {nd }}$ ed. Upper River Saddle, NJ: Prentice-Hall, 1997

[15] L.C. van Rijn, Principles of Coastal Morphology, Amsterdam: Aqua Publications, 1998

[16] C.D. Woodroffe, Coasts: Form, Process and Evolution, Cambridge: Cambridge University Press, 2002.

[17] M.G. Hughes and G. Masselink, An Introduction to Coastal Processes and Geomorphology, London: Routledge, 2003.

[18] R.A. Davis, Jr. and D.M. FitzGerald, Beaches and Coasts, Oxford: Blackwell, 2004

[19] M.L. Schwartz, ed., Encyclopedia of Coastal Science, Dordrecht: Springer, 2005.

[20] E. Bird, Coastal Geomorphology: An Introduction, $2^{\text {nd }}$ ed. Hoboken: John Wiley, 2008.

[21] S. Haslett, Coastal Systems, London: Routledge, 2008.

[22] R. Davison-Arnott, Introduction to Coastal Processes and Geomorphology, Cambridge: Cambridge University Press, 2010.

[23] E.C. F. Bird, ed., Encyclopedia of the World's Coastal Landforms, Dordrecht: Springer, 2010

[24] G. Masselink, G., M.G. Hughes and J. Knight, Introduction to Coastal Processes and Geomorphology, $2^{\text {nd }}$ ed. London: Taylor and Francis, 2011.

[25] USACE, Shore Protection Manual, 3 Volumes, Fort Belvoir, VA: U.S Army Coastal Engineering Research Centre, 1973.

[26] USACE, Engineering and Design. Coastal Geology. Manual No. 1110 2-1810, Washington, DC: U.S. Army Corps of Engineers, 1995.

[27] USACE, Coastal Engineering Manual. 6 Parts, Washington, DC: U.S Army Corps of Engineers, 2008.

[28] O.H. Pilkey and J.A.G. Cooper, The Last Beach, Durham, N.C.: Duke University Press, 2014

[29] A. Luijendijk, G. Hagenaars, R. Ranasinghe, F. Baart, G. Donchyts, and S. Aarninkhof, "The state of the world's beaches," Scientific Reports, vol. 8 (1), 2018. DOI: 10.1038/s41598-018-24630-6.

[30] J.L. Davies, “A morphogenic approach to world shorelines," Zeitschrift für Geomorphologie, vol. 8, pp. 27-42, 1964.

[31] M.G. Wolman and J.P. Miller, "Magnitude and frequency of forces in geomorphic processes," Journal of Geology, vol. 68 (1), pp. 54-74 1960.

[32] P.P. Wong, "Beach evolution between headland breakwaters," Shore and Beach, vol. 49 (3), pp. 3-12, 1981.

[33] P.P. Wong, "Impact of a sea level rise on the coasts of Singapore: preliminary observations," Journal of Southeast Asian Earth Sciences vol. 7, pp. 65-70, 1992

[34] P.P. Wong, "Impacts and recovery from a large tsunami: coasts of Aceh," Polish Journal of Environmental Studies, vol. 18, pp. 5-16, 2009.

[35] P.P. Wong, "Impacts, recovery and resilience of Thai tourist coasts to the 2004 Indian Ocean tsunami," in Natural Hazards in the AsiaPacific Region: Recent Advances and Emerging Concepts, J.P. Terry and J. Goff, eds. London: Geological Society of London, Special Publication 361, 2012, pp. 127-138.

[36] A.D. Short, "Wave-power and beach-stages: a global model," Proceedings, $16^{\text {th }}$ International Conference on Coastal Engineering, Hamburg, pp. 1145-1162, 1978.

[37] R. Silvester, "Headland defence of coasts," Proceedings, 15 International Conference on Coastal Engineering, Honolulu, pp. 13941406, 1976

[38] T. Tomascik, A.J. Mah, A. Nontji, and M.K. Moosa, The Ecology of the Indonesian Seas, Part Two, Hong Kong: Periplus Edition, 1997.

[39] T. Sunamura, Geomorphology of Rock Coasts, Chichester, NY: John Wiley, 1992.

[40] T. Bridges, R. Henn, S. Komlos, D. Scerno, T. Wamsley, and K. White, Coastal Risk Reduction and Resilience: Using the Full Array of Measures, Washington, DC: U.S. Army Corps of Engineers, 2013.

[41] USACE, Natural and Structural Measures for Shoreline Stabilization, Washington, DC: U.S. Army Corps of Engineers, 2015.

[42] E. Cohen-Shacham, G. Walters, C. Janzen, and S. Maginnis, eds. Nature-based Solutions to Address Global Societal Challenges, Gland IUCN, 2016.

[43] R. Misdorp, ed., Climate of Coastal Cooperation, Leiden: Coastal and Marine Union, 2011.

[44] RIBA (Royal Institute of British Architects), Living with Water: Visions of a Flooded Future, London, 2007

[45] A.J.M. Smits, P.H. Nienhuis, and H.L.F. Saeijs, "Changing estuaries, changing views," Hydrobiologia, vol. 565, pp. 339-355, 2006 
[46] R. Beavers, A. Babson, and C. Schupp, eds., Coastal Adaptation Strategies Handbook, NPS 999/134090, Washington, DC: National Park Service, 2016.

[47] P.P. Wong, "Coastal protection measures - case of Small Island Developing States to address sea-level rise," Asian Journal of Environment \& Ecology, vol. 6 (3), pp. 1-14, 2018. 